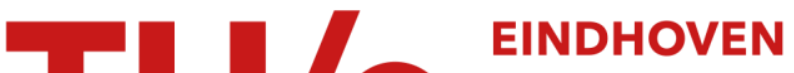

\section{Bioinspired magnetite crystallization directed by random copolypeptides}

\section{Citation for published version (APA):}

Lenders, J. J. M., Zope, H., Yamagishi, A., Bomans, P. H. H., Arakaki, A., Kros, A., With, de, G., \& Sommerdijk, N. A. J. M. (2015). Bioinspired magnetite crystallization directed by random copolypeptides. Advanced Functional Materials, 25(5), 711-719. https://doi.org/10.1002/adfm.201403585, https://doi.org/10.1002/adfm.201403585

DOI:

10.1002/adfm.201403585

10.1002/adfm.201403585

\section{Document status and date:}

Published: 04/02/2015

\section{Document Version:}

Publisher's PDF, also known as Version of Record (includes final page, issue and volume numbers)

\section{Please check the document version of this publication:}

- A submitted manuscript is the version of the article upon submission and before peer-review. There can be important differences between the submitted version and the official published version of record. People interested in the research are advised to contact the author for the final version of the publication, or visit the $\mathrm{DOI}$ to the publisher's website.

- The final author version and the galley proof are versions of the publication after peer review.

- The final published version features the final layout of the paper including the volume, issue and page numbers.

Link to publication

\section{General rights}

Copyright and moral rights for the publications made accessible in the public portal are retained by the authors and/or other copyright owners and it is a condition of accessing publications that users recognise and abide by the legal requirements associated with these rights.

- Users may download and print one copy of any publication from the public portal for the purpose of private study or research.

- You may not further distribute the material or use it for any profit-making activity or commercial gain

- You may freely distribute the URL identifying the publication in the public portal.

If the publication is distributed under the terms of Article 25fa of the Dutch Copyright Act, indicated by the "Taverne" license above, please follow below link for the End User Agreement:

www.tue.nl/taverne

Take down policy

If you believe that this document breaches copyright please contact us at:

openaccess@tue.nl

providing details and we will investigate your claim. 


\title{
Bioinspired Magnetite Crystallization Directed by Random Copolypeptides
}

\author{
Jos J. M. Lenders, Harshal R. Zope, Ayana Yamagishi, Paul H. H. Bomans, \\ Atsushi Arakaki, Alexander Kros, Gijsbertus de With, and Nico A. J. M. Sommerdijk**
}

Control over magnetite $\left(\mathrm{Fe}_{3} \mathrm{O}_{4}\right)$ formation is difficult to achieve in synthetic systems without using non-aqueous media and high temperatures. In contrast, Nature employs often intrinsically disordered proteins to tightly tailor the size, shape, purity, and organization of the nanocrystals to optimize their magnetic properties. Inspired by such "flexible polyelectrolytes," here random copolypeptides having different amino acid compositions are used as control agents in the bioinspired coprecipitation of magnetite through a ferrihydrite precursor, following a recently developed mineralization protocol. Importantly, the copolypeptide library is designed such that the amino acid composition can be optimized to simultaneously direct the size of the nanoparticles as well as their dispersibility in aqueous media in a one-pot manner. Acidic amino acids are demonstrated to regulate the crystal size by delaying nucleation and reducing growth. Their relative content thus can be balanced to tune between the superparamagnetic and ferrimagnetic regimes, and high contents of negatively charged amino acids result in colloidal stabilization of superparamagnetic nanoparticles at high $\mathrm{pH}$. Conversely, with positively charged lysine-rich copolypeptides ferrimagnetic crystals are obtained which are stabilized at neutral $\mathrm{pH}$ and self-organize in chains, as visualized by cryotransmission electron microscopy. Altogether, the presented findings give important insights for the future development of additive-mediated nanomaterial syntheses.

\section{Introduction}

Magnetite $\left(\mathrm{Fe}_{3} \mathrm{O}_{4}\right)$ is a biologically and technologically important magnetic iron oxide of which the magnetic properties depend on the size, shape, purity, and organization of the crystals. ${ }^{[1-3]}$ Magnetite biominerals encompass well-defined, often single-domain crystals as, e.g., encountered in the magnetosomes of magnetotactic bacteria, ${ }^{[4]}$ but also in the magnetoreceptive organs of migratory birds, ${ }^{[5]}$ honeybees, ${ }^{[5 a, 6]}$ and certain fish. ${ }^{[5,7]}$ In contrast, the most commonly used industrial process for magnetite production up to date, direct coprecipitation of $\mathrm{Fe}^{(\mathrm{II})}$ and $\mathrm{Fe}^{(\mathrm{III})}$ ions from solution, typically yields small (<20 $\mathrm{nm}$ ) superparamagnetic particles with little control over size or shape, ${ }^{[8]}$ while protocols allowing better control usually involve non-aqueous media and/or high temperatures. ${ }^{[8 \mathrm{~d}, \mathrm{e}]}$

Applying strategies from biomineralization in materials chemistry could open the door to the additive-directed synthesis of magnetite-based nanomaterials with control over the dimensions and organization of the particles and thereby their magnetic properties, using green, bioinspired production methods, i.e., using aqueous media and ambient temperatures. ${ }^{[3 a, 9]}$ However, compared to other biominerals (e.g., calcium carbonate, calcium phosphate, and silica), for which the biomimetic synthesis of materials with controlled morphology through the action of designer molecules is well-documented, ${ }^{[10]}$ far less activities have focused on the bioinspired mineralization of magnetite.

For the magnetite in magnetotactic bacteria ${ }^{[11]}$ and in the outer layers of chiton teeth ${ }^{[12]}$ ferrihydrite has been indicated as an intermediate precursor phase. ${ }^{[13]}$ In the case of the magnetosomes, the magnetite formation takes place within the confined
J. J. M. Lenders, P. H. H. Bomans, Prof. Dr. G. de With,

Prof. Dr. N. A. J. M. Sommerdijk

Laboratory of Materials and Interface Chemistry and

Soft Matter CryoTEM Research Unit

Department of Chemical Engineering and Chemistry

Eindhoven University of Technology

P.O. Box 513, 5600, MB, Eindhoven, The Netherlands

E-mail: N.Sommerdijk@tue.nl

J. J. M. Lenders, P. H. H. Bomans, Prof. Dr. N. A. J. M. Sommerdijk Institute for Complex Molecular Systems

Eindhoven University of Technology

P.O. Box 513, 5600, MB, Eindhoven, The Netherlands
H. R. Zope, Dr. A. Kros

Leiden Institute of Chemistry

Leiden University

P.O. Box 9502, 2300, RA, Leiden, The Netherlands

A. Yamagishi, Dr. A. Arakaki

Department of Biotechnology and Life Science

Faculty of Engineering

Tokyo University of Agriculture and Technology
2-24-16 Naka-cho, Koganei, Tokyo 184-8588, Japan

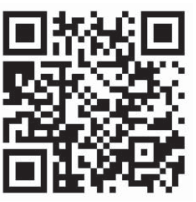

DOI: 10.1002/adfm.201403585 
space of vesicles, ${ }^{[4 a, b, 14]}$ which allows the occurrence of a single nucleation event inside such a vesicle and its subsequent growth into a crystal with controlled dimensions. This process is under strict control of specialized biomolecules, ${ }^{[14,15]}$ typically acidic proteins associated with the magnetosome membrane, which tightly bind to magnetite and allow for control over the nucleation and growth - and hence the size and morphology - of the resulting crystals. Such a strategy is believed to avoid conditions of high supersaturation, and - together with the confinement effect - to prohibit uncontrolled nucleation and limited growth, which is typical for direct magnetite precipitation from solution through ion-by-ion growth.

However, even in in vitro assays isolated magnetite biomineralization proteins can provide some control over magnetite crystallization as long as the reaction kinetics are kept under control, although not many examples exist. In particular the magnetosome protein Mms6 and its active C-terminal part M6A have been found to regulate the nucleation and growth of magnetite in vitro. ${ }^{[15 c, 16]}$ For example, Prozorov et al. demonstrated the formation of appreciable and uniform magnetite nanocrystals through the action of Mms6 during coprecipitation inside a gel medium, ${ }^{[16 a]}$ thereby creating diffusion-limited reaction kinetics.

For many biomineralization proteins it has been found that they are intrinsically disordered and have large unstructured regions in their amino acid sequence that can freely interact with the biomineral during its development. ${ }^{[17]}$ These observations imply that the overall physicochemical properties of their active domains - such as charge (density) and hydrophobicity - and not (the secondary structures of) the precise amino acid sequences are responsible for their impact on bio(mimetic) mineralization: the so-called flexible polyelectrolyte hypothesis. ${ }^{[17 b]}$ Even though for the specific case of Mms6 it has been proposed that the amino acid sequence of the C-terminus is important for efficient $\mathrm{Fe}^{(\mathrm{III})}$ binding and morphological control, ${ }^{[18]}$ it still is of great interest to investigate the minimal functional requirements of biomineralization proteins in bioinspired mineralization experiments using additives of reduced complexity, such as simple polymeric additives, nonetheless aiming at achieving similar control. ${ }^{[3 a, 9]}$

Moreover, such polymer additives potentially may act as surfactants, thereby functionalizing the surface of the magnetite nanoparticles. In this way they could - in addition to controlling nucleation and growth - simultaneously enhance the dispersibility of the nanoparticles and lead to colloidally stable systems in a one-pot strategy. Such magnetic dispersions have potential in various applications, especially in the medical field, e.g., in contrast agents for magnetic resonance imaging (MRI), hyperthermia therapy, and targeted drug delivery, but also as catalysts, magnetic inks, and data storage media. ${ }^{[8 d, e, 19]}$ Currently these materials generally are only accessible through laborious multi-step functionalization and phase-transfer procedures.

Baumgartner et al. reported the formation of ferrimagnetic magnetite nanoparticles by controlled dosing of the reactants, ${ }^{[20]}$ and although their conditions allowed for continuous crystal growth, they also resulted in ongoing nucleation, leading to polydisperse products. However, when poly(L-arginine) was used as a positively charged nucleation and growth controller, the crystals became colloidally stabilized in aqueous dispersion and their size distribution was significantly reduced. In contrast, negatively charged proteins were only found to inhibit magnetite formation. ${ }^{21]}$

We recently reported on a bioinspired coprecipitation method in which the $\mathrm{pH}$ and thereby the supersaturation of a $\mathrm{Fe}^{(\mathrm{II})}: 2 \mathrm{Fe}^{(\mathrm{III})}$ solution was increased slowly by the in-diffusion of ammonia, thereby proceeding through a 2-line ferrihydrite phase which later converts to magnetite under mildly alkaline conditions $(\mathrm{pH} \approx 7.8) .{ }^{[2]}$ The $\mathrm{NH}_{3}$ influx and the Fe concentration could be varied to manipulate the precipitation kinetics and thereby the resulting crystal size, and by limiting the $\mathrm{NH}_{3}$ influx and the Fe concentration sufficiently (to $1.2 \times 10^{-3} \mathrm{M} \mathrm{h}^{-1}$ and $3 \times 10^{-3} \mathrm{M}$, respectively) crystals as large as $60 \pm 21 \mathrm{~nm}$ could be obtained. In this assay, the negatively charged M6A peptide was used as a nucleation and growth control agent to improve the morphology, functional properties, and dispersibility of the nanoparticles, demonstrating the suitability of this method for the rapid screening of additive effects.

In addition, we designed and synthesized a class of disordered, random copolypeptides with excellent control over the degree of polymerization (DP), polydispersity index (PDI), and composition. ${ }^{[1,22]}$ By systematic variation of the amino acid composition we created a complete library of polypeptides with different charge and hydrophobicity. These macromolecules thus are suitable to employ as control agents in studying the effects of such physicochemical properties on the nucleation and growth of crystals in bioinspired mineralization experiments, as well as their capability to functionalize the surface of the crystals to improve their dispersibility.

In the present study we employ poly(L-aspartic acid) (pAsp), poly(L-glutamic acid) (pGlu), poly(L-lysine) (pLys) and random copolypeptides of aspartic acid (D) and serine (S) as well as of glutamic acid (E), lysine (K), and alanine (A) with varying composition (Table 1 and Table S1, Supporting Information) in our biomimetic coprecipitation method to direct the size (distribution), morphology, magnetic properties, dispersion, and organization of magnetite nanoparticles. By systematically varying the monomer composition we can assess the impact of compositional properties such as net charge/charge density and hydrophilicity on magnetite formation, while cancelling out any structural effects. We designed the copolypeptides such that we can find the optimal content of either negatively or positively charged residues to control magnetite nucleation and growth by interacting with the mineral, while - at the same time - the remaining, non-interacting hydrophilic residues could improve the dispersibility of the products.

\section{Results and Discussion}

Briefly, the biomimetic magnetite coprecipitation protocol involves the gradual $\mathrm{pH}$ increase of a solution containing $\mathrm{FeCl}_{3}$ $\left(2 \times 10^{-3} \mathrm{M}\right)$ and $\mathrm{FeCl}_{2}\left(1 \times 10^{-3} \mathrm{M}\right)$ through the slow in-diffusion of $\mathrm{NH}_{3}\left(1.2 \times 10^{-3} \mathrm{M} \mathrm{h}^{-1}\right)$. ${ }^{[2]}$ First, we used random copolypeptides of aspartic acid (D) and serine (S) in molar ratios of 20/80, 50/50, and 80/20 (D20S80, D50S50, and D80S20, respectively) as macromolecular additives in this crystallization experiment (Figure 1 and Figure S1 and Table S2, Supporting Information), aiming at employing the $\mathrm{D}$ residues to interact with the 
Table 1. Overview of all (co)polypeptides applied in this work, the sample codes used for reference and their amino acid composition.

\begin{tabular}{|c|c|}
\hline Sample code & Experimental composition $^{\text {a) }}[\mathrm{mol} \%]$ \\
\hline $\mathrm{pAsp}=\mathrm{D} 100$ & {$[\mathrm{D}]_{100 \%}$} \\
\hline pClu = E100 & {$[E]_{100 \%}$} \\
\hline $\mathrm{pLys}=\mathrm{K} 100$ & {$[\mathrm{~K}]_{100 \%}$} \\
\hline D20S80 & {$[\mathrm{D}]_{20 \%}[\mathrm{~S}]_{80 \%}$} \\
\hline D50S50 & {$[\mathrm{D}]_{50 \%}[\mathrm{~S}]_{50 \%}$} \\
\hline $\mathrm{D} 80 \mathrm{~S} 20$ & {$[\mathrm{D}]_{80 \%}[\mathrm{~S}]_{20 \%}$} \\
\hline E10 & {$[\mathrm{E}]_{10 \%}[\mathrm{~K}]_{41 \%}[\mathrm{~A}]_{49 \%}$} \\
\hline E19 & {$[\mathrm{E}]_{19 \%}[\mathrm{~K}]_{36 \%}[\mathrm{~A}]_{45 \%}$} \\
\hline $\mathrm{E} 33^{\mathrm{b})}$ & {$[\mathrm{E}]_{31 \%}[\mathrm{~K}]_{31 \%}[\mathrm{~A}]_{38 \%}$} \\
\hline E39 & {$[\mathrm{E}]_{39 \%}[\mathrm{~K}]_{28 \%}[\mathrm{~A}]_{33 \%}$} \\
\hline E48 & {$[\mathrm{E}]_{48 \%}[\mathrm{~K}]_{22 \%}[\mathrm{~A}]_{30 \%}$} \\
\hline E59 & {$[\mathrm{E}]_{59 \%}[\mathrm{~K}]_{19 \%}[\mathrm{~A}]_{22 \%}$} \\
\hline E67 & {$[\mathrm{E}]_{67 \%}[\mathrm{~K}]_{18 \%}[\mathrm{~A}]_{15 \%}$} \\
\hline E76 & {$[\mathrm{E}]_{76 \%}[\mathrm{~K}]_{14 \%}[\mathrm{~A}]_{10 \%}$} \\
\hline $\mathrm{K} 10$ & {$[\mathrm{E}]_{41 \%}[\mathrm{~K}]_{10 \%}[\mathrm{~A}]_{49 \%}$} \\
\hline $\mathrm{K} 31^{\mathrm{b})}$ & {$[\mathrm{E}]_{31 \%}[\mathrm{~K}]_{31 \%}[\mathrm{~A}]_{38 \%}$} \\
\hline K45 & {$[\mathrm{E}]_{27 \%}[\mathrm{~K}]_{45 \%}[\mathrm{~A}]_{28 \%}$} \\
\hline K81 & {$[\mathrm{E}]_{09 \%}[\mathrm{~K}]_{81 \%}[\mathrm{~A}]_{10 \%}$} \\
\hline A05 & {$[\mathrm{E}]_{49 \%}[\mathrm{~K}]_{46 \%}[\mathrm{~A}]_{05 \%}$} \\
\hline A $38^{b)}$ & {$[\mathrm{E}]_{31 \%}[\mathrm{~K}]_{31 \%}[\mathrm{~A}]_{38 \%}$} \\
\hline A59 & {$[\mathrm{E}]_{21 \%}[\mathrm{~K}]_{20 \%}[\mathrm{~A}]_{59 \%}$} \\
\hline
\end{tabular}

a) Determined from ${ }^{1} \mathrm{H}$ NMR data; $[1,22]$ b) $\mathbf{E} 3 \mathbf{1}=\mathbf{K} 3 \mathbf{1}=\mathbf{A} 38$.

mineral during its formation and the $\mathrm{S}$ residues to enhance the colloidal stability of the products. ${ }^{[23]}$

D20S80 only had a small effect on the formed product and the obtained crystals were 44-48 $\pm 11-13 \mathrm{~nm}$ for all different amino acid (AA)/Fe ratios used, as compared to $60 \pm 21 \mathrm{~nm}$ for the control experiment without additives (Figure 1a). ${ }^{[2]}$ However, by increasing the relative concentration of D20S80 the morphology gradually changed from mainly facetted to mainly rounded particles (Figure S1, Supporting Information). D50S50 showed more pronounced effects on the size and shape of the formed crystals. While at an AA/Fe ratio of $1 / 100$ again similar facetted crystals of $43 \pm 12 \mathrm{~nm}$ were obtained, increasing the $\mathrm{AA} / \mathrm{Fe}$ ratio resulted in rounded crystals with sizes of $44 \pm 15 \mathrm{~nm}$ and $33 \pm 9 \mathrm{~nm}$ for $\mathrm{AA} / \mathrm{Fe}$ ratios of $1 / 33$ and $1 / 20$, respectively. In line with these results, crystal growth was even further restricted in the presence of D80S20, resulting in rounded crystals of $44 \pm 13 \mathrm{~nm}, 30 \pm 9 \mathrm{~nm}$, and $27 \pm 7 \mathrm{~nm}$ for $\mathrm{AA} / \mathrm{Fe}$ ratios of $1 / 100,1 / 33$, and $1 / 20$, respectively.

The differences in average crystal sizes were reflected in the magnetic properties of the materials, as determined by vibrating sample magnetometry (VSM, Figure 1c-e and Figure S2, Supporting Information). The 40-50 nm crystals obtained for low $\mathrm{AA} / \mathrm{Fe}$ ratios and/or low D content all showed ferrimagnetic behavior with a remnant magnetization $M_{\mathrm{r}}$ of $\approx 20 \mathrm{Am}^{2} \mathrm{~kg}^{-1}$ and a coercivity $H_{\mathrm{c}}$ of $\approx 10 \mathrm{mT}$, in line with literature results for nano-sized magnetite. ${ }^{[3 \mathrm{~b}-\mathrm{e}]}$ As expected, both properties were reduced by a factor of $\approx 2$ for the smaller $(\approx 30 \mathrm{~nm})$ crystals (Figure 1c-e). At the same time, the saturation magnetization $M_{s}$ dropped from $\approx 80$ to $\approx 70 \mathrm{Am}^{2} \mathrm{~kg}^{-1}$ (Figure S2, Supporting Information).

The sample synthesized in the presence of D50S50 with an $\mathrm{AA} / \mathrm{Fe}$ ratio of $1 / 20$ displayed self-assembly of the rounded $33 \pm 9 \mathrm{~nm}$ magnetite crystals in strings (Figure 1b), which is attributed to the alignment of the permanent magnetic dipoles of the ferrimagnetic particles. ${ }^{[24]}$ Interestingly, D50S50 has the same negative charge density as the active M6A peptide derived from the Mms6 protein involved in magnetite biomineralization, ${ }^{[16 c]}$ and we found this peptide to have similar effects on the size (distribution), morphology, magnetic properties, and organization of the obtained crystals. ${ }^{[2]}$

Thus, although the DS copolypeptides could be employed to tune the properties of the synthesized materials as a function of their negative charge density and relative concentration, both these parameters are obviously not independent: similar results could be obtained, for instance, by increasing the D content from $50 \mathrm{~mol} \%$ to $80 \mathrm{~mol} \%$ if simultaneously the $\mathrm{AA} / \mathrm{Fe}$ ratio was decreased from $1 / 20$ to $1 / 33$ (Figure S1, Supporting Information). This suggested that the same effects should be achievable with poly(L-aspartic acid) (pAsp or D100) alone.

Indeed, pAsp was found to be an even more active growth control agent as compared to the DS copolypeptides and rounded nanoparticles with sizes of $31 \pm 8 \mathrm{~nm}, 18 \pm 5 \mathrm{~nm}$, $14 \pm 4 \mathrm{~nm}$, and $13 \pm 6 \mathrm{~nm}$ were obtained for Asp/Fe ratios of $1 / 100,1 / 33,1 / 20$, and $1 / 10$, respectively (Figures $1 \mathrm{a}$ and 2 ). Selected-area electron diffraction (SAED) demonstrated that in all cases the product was magnetite (Figure S3, Supporting Information).

To further elucidate the role of pAsp, the $\mathrm{pH}$ of the Fe solution was monitored over time during the influx of $\mathrm{NH}_{3}$. This allowed the identification of the magnetite nucleation event as a local dip in the $\mathrm{pH}$-time curve (Figure 2). While the nucleation of magnetite was observed after $\approx 7.4 \mathrm{~h}$ at $\mathrm{pH} \approx 7.8$ in the control experiment without pAsp (Figure 2a), ${ }^{[2]}$ this event was delayed in time when increasing Asp/Fe ratios were applied. Nucleation thereby also occurred at an increasingly higher $\mathrm{pH}$ (up to $\approx 9)$ due to the continuous influx of $\mathrm{NH}_{3}$. Notably, at the highest Asp/Fe ratio of $1 / 10$ the nucleation event could no longer be distinguished (Figure 2e), while the formation of $13 \pm 6 \mathrm{~nm}$ magnetite nanoparticles still occurred.

UV-vis measurements showed distinct differences between the spectra of solutions of $\mathrm{FeCl}_{2}$ and/or $\mathrm{FeCl}_{3}$ at $\mathrm{pH}$ 3-4 with and without pAsp (Figure S4, Supporting Information), indicating that the negatively charged polypeptide binds both $\mathrm{Fe}^{(\mathrm{II})}$ and $\mathrm{Fe}^{(\mathrm{III})}$ ions in the initial solution, in analogy to what has been found for the Mms6 protein. ${ }^{[18]}$ Indeed, poly(L-lysine) (pLys) - being positively charged - did not alter the UV-vis spectra of $\mathrm{FeCl}_{2} / \mathrm{FeCl}_{3}$ solutions (Figure S4, Supporting Information), indicating little interaction. In addition, pLys had hardly any effect on the obtained product as compared to the control without additives and the obtained crystal dimensions were $58 \pm 15 \mathrm{~nm}$ for a Lys/Fe ratio of $1 / 10$, while their nucleation was only slightly delayed and occurred at $\mathrm{pH} \approx 8.0$ (Figure $2 \mathrm{f}$ ).

However, apparently the interaction of negatively charged residues with iron ions in the initial solution does not prevent the iron from precipitating as ferrihydrite and ultimately 

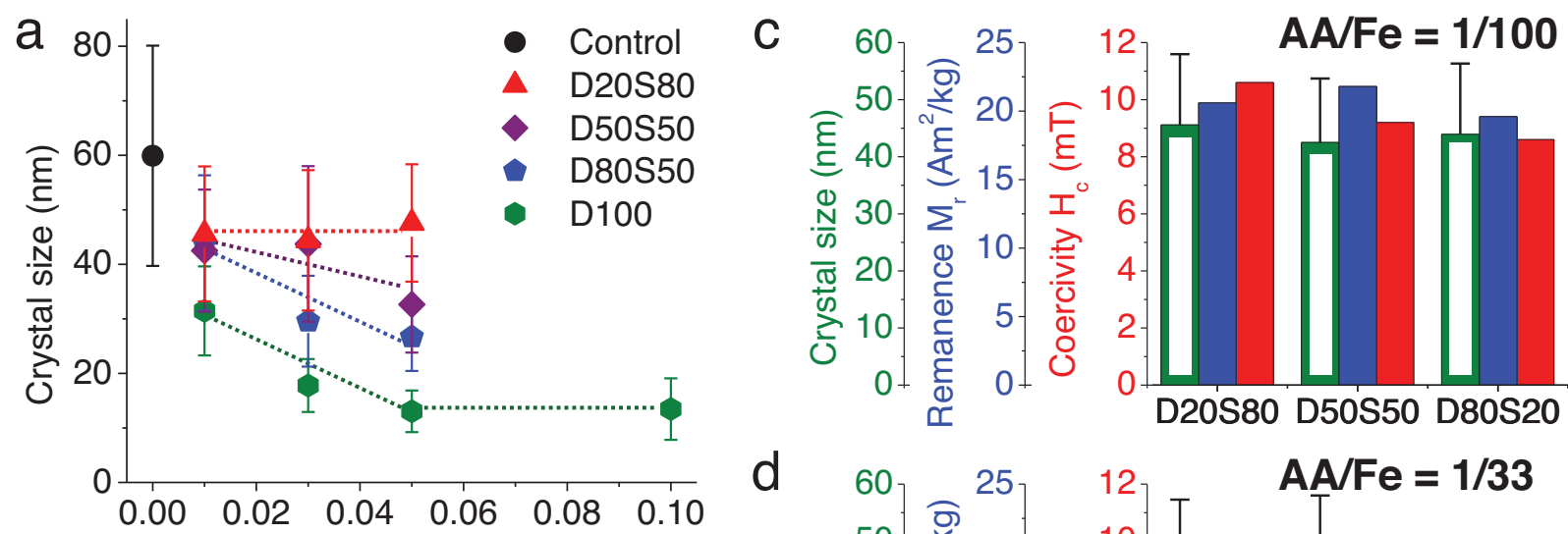

Amino acid/Fe ratio $(\mathrm{mol} / \mathrm{mol})$

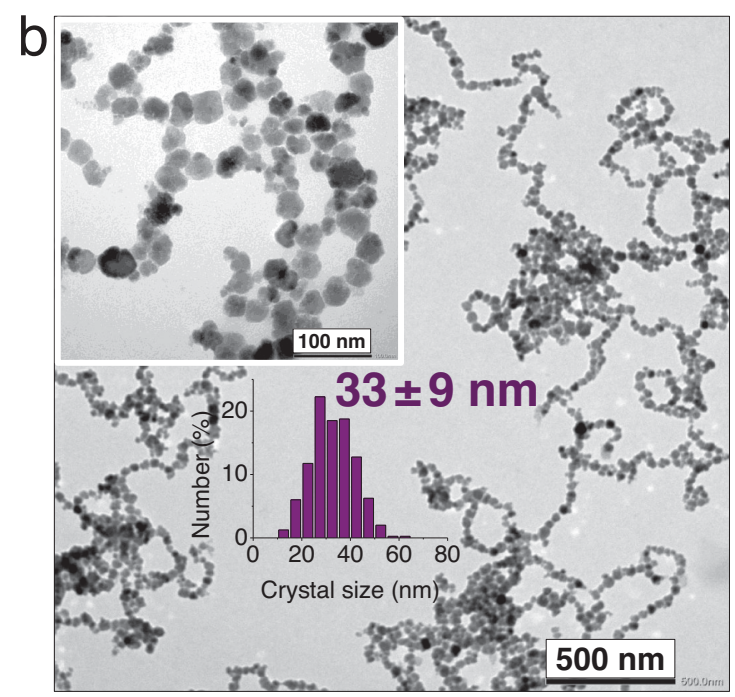

\section{d}

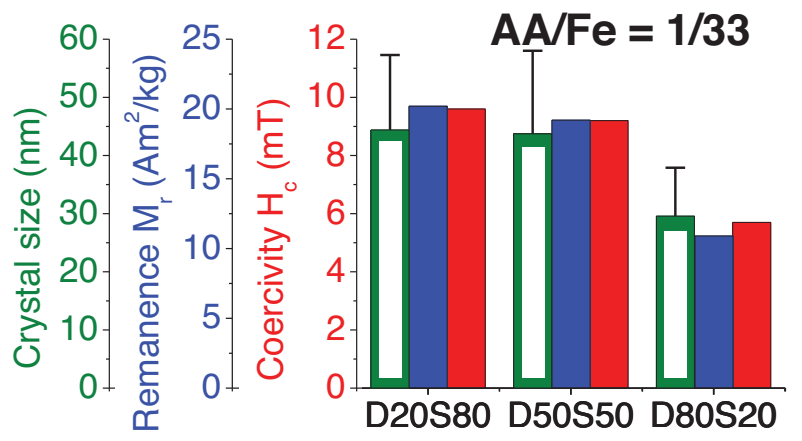

e

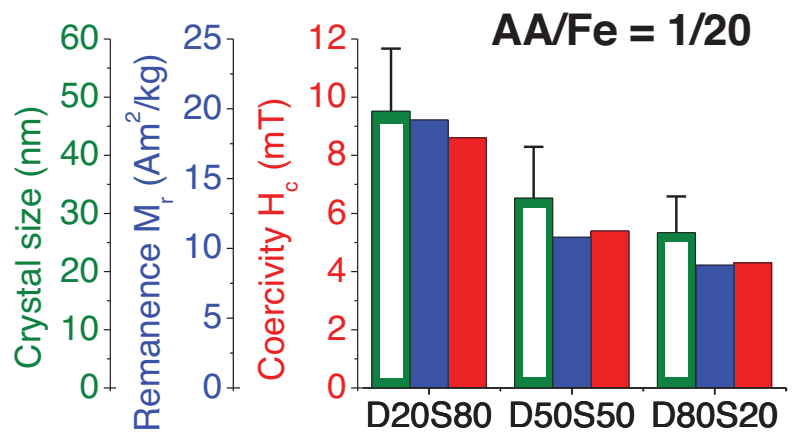

Figure 1. a) Average crystal sizes with corresponding standard deviations of the products of slow coprecipitation by $\mathrm{NH}_{3}$ diffusion without and with the different DS copolypeptides and pAsp (D100) as additives as a function of the AA/Fe ratio, showing that the obtained crystal size depends on the relative polypeptide concentration as well as the polypeptide composition ( $D$ content). The dashed lines are only to guide the eye. b) TEM image of the $33 \pm 9 \mathrm{~nm}$ magnetite nanoparticles formed in the presence of D50S50 (AA/Fe ratio $=1 / 20$ ), showing alignment in strings. The insets show a higher magnification and the corresponding crystal size distribution. c-e) Crystal sizes, remnant magnetization $\left(M_{r}\right)$ and magnetic coercivity $\left(H_{c}\right)$ of the products in the presence of the different DS copolypeptides and in different AA/Fe ratios, showing a systematic decrease in crystal size - and therefore a corresponding decrease in $M_{r}$ and $H_{c}$ - with increasing $A A / F e$ ratio and $D$ content.

converting to magnetite at higher $\mathrm{pH}$. In all cases, the increase in solution $\mathrm{pH}$ is observed between $\approx 6-7 \mathrm{~h}$ reaction time from a plateau at $\approx 3$ to $>7$ (Figure 2), which is when the solution absorbed $6 \times 10^{-3} \mathrm{M} \mathrm{NH}_{3}$ to precipitate virtually all $2 \times 10^{-3} \mathrm{M}$ $\mathrm{Fe}^{(\mathrm{III})} \cdot{ }^{[2]}$ Moreover, from the dry mass of the end products we find that in all cases nearly all initial iron eventually is converted to magnetite, which we attribute to the extremely low solubility of magnetite in alkaline conditions. ${ }^{[25]}$ This indicates that, even though pAsp binds iron ions at low $\mathrm{pH}$, the polymer has little impact on iron activity at the $\mathrm{pH}$ values where magnetite is formed. Moreover, this means that the observations are not due to a reduction of supersaturation related to metal binding by the polymer, as this would go hand in hand with a lower yield. Instead, this suggests that pAsp (as opposed to pLys) acts as a nucleation inhibitor by binding to the ferrihydrite/Fe(II) precursor through charge interactions, and that because of this stabilization the conversion of the precursor to magnetite only takes place at higher $\mathrm{pH}$ and thus is delayed. Further, it is known that the alkalinity of the medium in which magnetite forms has an influence on the obtained particle dimensions ${ }^{[20,21]}$ and that a higher $\mathrm{pH}$ results in smaller crystal sizes due to lowering of the surface tension, ${ }^{[26]}$ which is fully in line with our results.

Unfortunately, the magnetite nanoparticles obtained in the presence of the DS copolypeptides or pAsp did not show any significant stabilization in dispersion over time, and after 7 days all products but one showed sedimentation, both in neutral $(\mathrm{pH} 7)$ and alkaline $(\mathrm{pH} 10)$ media (Figure S5, Supporting Information). Only the sample with the highest pAsp content $($ Asp $/ \mathrm{Fe}$ ratio $=1 / 10)$ displayed permanent colloidal stabilization at $\mathrm{pH} 10$, presumably due to the significant amount of polyelectrolyte present in combination with the increased zeta 

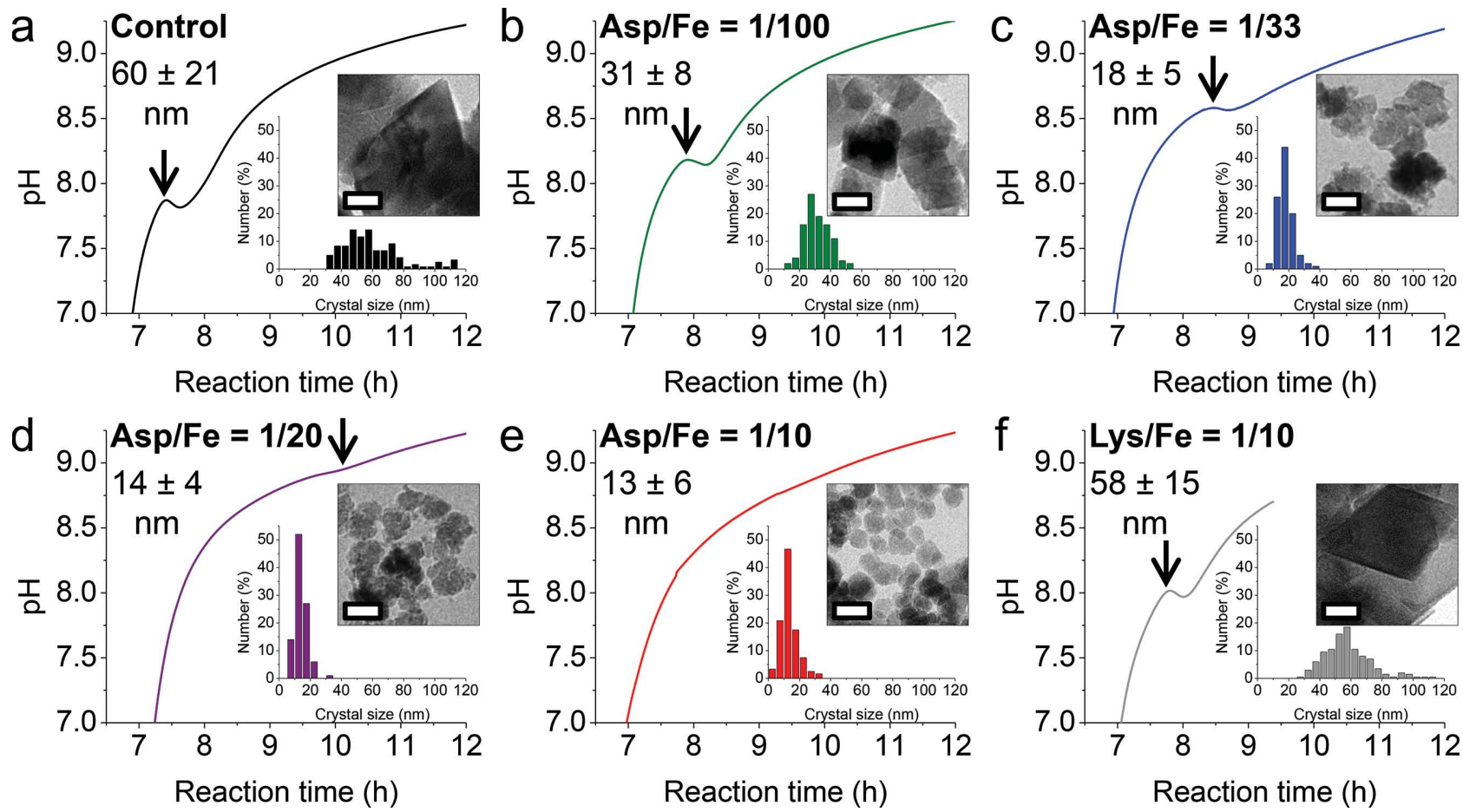

Figure 2. Plots of the magnetite nucleation events during slow coprecipitation by $\mathrm{NH}_{3}$ diffusion a) without and b-e) with pAsp (D100) in different Asp/Fe ratios with resulting crystal size distributions and corresponding TEM images (scale bars are $20 \mathrm{~nm}$ ), showing delayed nucleation at higher pH resulting in smaller crystals for higher Asp/Fe ratios, in contrast to the observations $\mathrm{f}$ ) with pLys (Lys/Fe ratio = 1/10).

potential of magnetite in alkaline conditions and the reduced size of the nanocrystals. ${ }^{[27]}$

Thus, although the inhibitory effects of the negatively charged polypeptide pAsp alone could be employed to regulate the size of magnetite nanoparticles by means of the Asp/Fe ratio, colloidal stability was obtained only at high additive concentrations, where the inhibitory effects of the polypeptide on the nucleation and growth of magnetite resulted only in small and thus superparamagnetic particles. Further, the hydrophilic but neutrally charged serine residues in the DS copolypeptides did not provide any significant improvement of the dispersibility of the products. Therefore, the slow coprecipitation protocol was used to grow magnetite in the presence of copolypeptides with different E, K, and A content (Figures 3 and 4) ${ }^{[1]}$ In combination with the $\mathrm{AA} / \mathrm{Fe}$ ratio, variation of their $\mathrm{E}$ content was expected to give rise to similar major effects on magnetite nucleation and growth as variation of the D content in the DS copolypeptides did. Moreover, the $\mathrm{K}$ residues may, once protonated, improve the dispersibility as compared to the neutrally charged $\mathrm{S}$ residues, while the hydrophobic A residues may increase the amphiphilic character of the polymer additives.

First, experiments were carried out using a series of copolypeptides in which the glutamic acid content was varied from 10 to 100 mol\% while keeping the lysine and alanine contents in equal contributions, and applying $\mathrm{AA} / \mathrm{Fe}$ ratios of $1 / 100,1 / 33,1 / 20$, and $1 / 10$ (Figure 3 and Figures S6-S8 and Tables S3 and S4, Supporting Information). Similar to the DS copolypeptides and pAsp, in all cases the crystals were increasingly smaller for higher AA/Fe ratios (Figure 3a). Importantly, this effect was stronger for additives with higher $\mathrm{E}$ contents, suggesting that the negatively charged E residues are dominant over $\mathrm{K}$ and $\mathrm{A}$ residues in affecting the obtained particle size (Figure 3a). Indeed, also for copolypeptides in which the $\mathrm{K}$ or A content was varied the magnetite crystal size decreased with increasing E content (Table S5 and Figures S9 and S10, Supporting Information).

When the $\mathrm{pH}$ of the $\mathrm{Fe}$ solutions at the highest additive concentration used $(\mathrm{AA} / \mathrm{Fe}$ ratio $=1 / 10)$ was monitored over time, it was again observed that the nucleation of magnetite was delayed in all cases as compared to the control experiment without additives (Figure 2a) and occurred at higher $\mathrm{pH}$ values for copolypeptides with higher E contents (Figure 3), in line with the results obtained with different concentrations of pAsp (Figure 2). Also similarly, the size of the crystals systematically decreased as a function of the E content of the copolypeptides, from $42 \pm 10 \mathrm{~nm}$ for E10 to $11 \pm 4 \mathrm{~nm}$ for E100 (Figure $4 \mathrm{a}$ ). This demonstrates that both aspartic acid and glutamic acid residues have inhibitory effects on the nucleation of magnetite, and that these effects can be used to systematically tune the crystal size, as a function of the relative polypeptide concentration as well as the polypeptide composition.

Also the morphology of the crystals was affected as a function of the E content of the copolypeptides, going from $63 \%$ well-facetted crystals in the control experiment without additives to $>90 \%$ rounded crystals for experiments with copolypeptides having a high glutamic acid content (Figure S11, Supporting Information), suggesting that the glutamic acid residues did not only affect the nucleation but also the growth of the magnetite nanoparticles. We believe this to be a similar effect as observed for pAsp on magnetite formation in a partial 

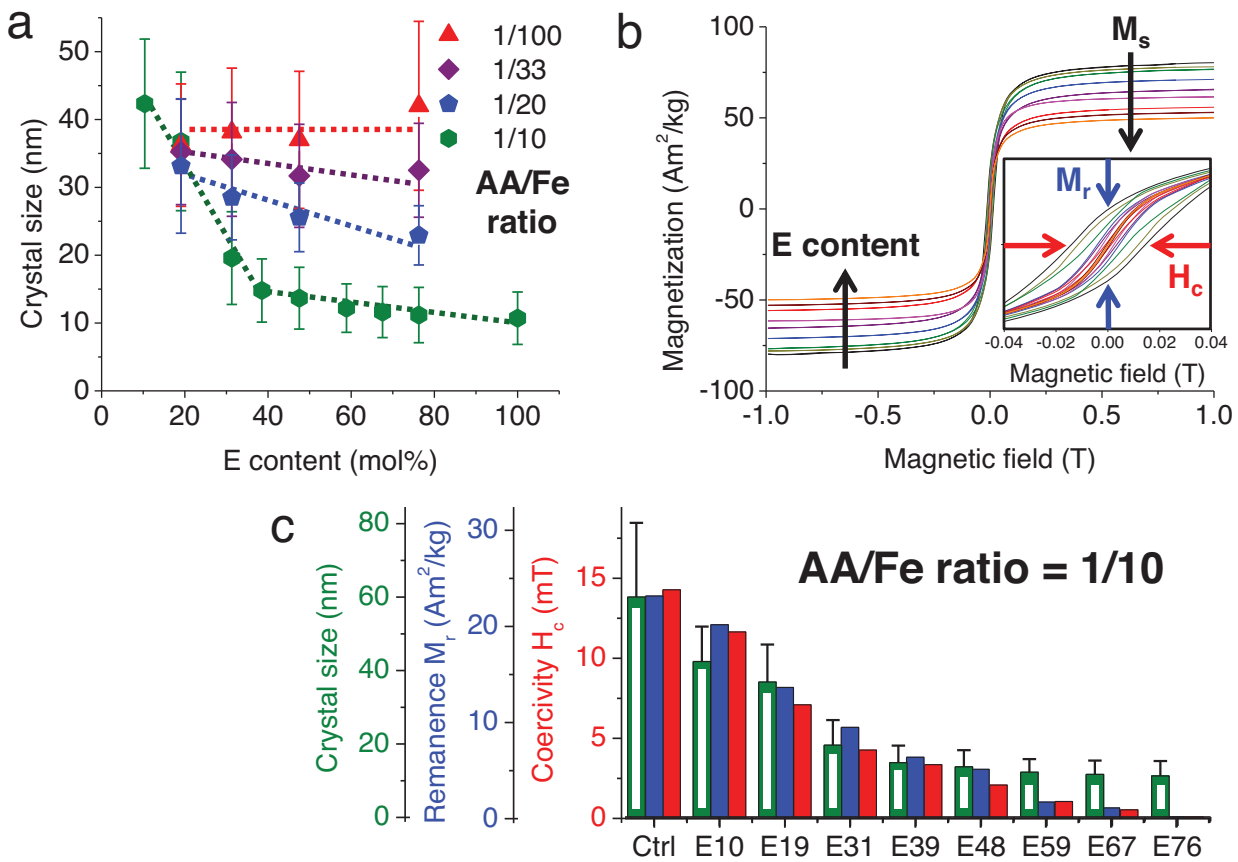

Figure 3. a) Average crystal sizes with corresponding standard deviations of the products of slow coprecipitation by $\mathrm{NH}_{3}$ diffusion in the presence of different EKA copolypeptides and in different AA/Fe ratios as a function of the $E$ content, showing that the obtained crystal size depends on the relative polypeptide concentration as well as the polypeptide composition (E content). The dashed lines are only to guide the eye. b) VSM curves of the products without and with E10-E76 as additives $(\mathrm{AA} / \mathrm{Fe}$ ratio $=1 / 10)$, showing that the saturation magnetization $\left(M_{s}\right)$, remnant magnetization $\left(M_{r}\right)$, and magnetic coercivity $\left(H_{c}\right)$ (see zoomed-in inset) decrease with increasing E content. c) Corresponding crystal sizes, remnant magnetization $\left(M_{r}\right)$, and magnetic coercivity $\left(H_{c}\right)$, showing a systematic decrease in crystal size - and therefore a transition from ferrimagnetic to superparamagnetic behavior - with increasing E content.

oxidation reaction, ${ }^{[28]}$ where it was demonstrated that - even for comparable particle sizes - negatively charged residues produce a nonspecific growth reduction of magnetite crystals as compared to the control reaction.

VSM showed that the remnant magnetization and magnetic coercivity decreased as a function of the crystal size, going from ferrimagnetic behavior for the polypeptides with low glutamic acid content to superparamagnetic behavior (no magnetic hysteresis) for the polypeptides with high glutamic acid content (Figure $3 \mathrm{~b}, \mathrm{c}$ ), again in line with published data. ${ }^{3 \mathrm{~b}-\mathrm{e}]}$

For the EKA copolypeptides, the interaction of the polypeptides with the mineral during nucleation and growth not only affected the magnetite morphology, but also increased its dispersibility in the aqueous medium, as the polypeptide chains apparently immobilize on the surface of the crystals. The negatively charged E residues apparently interact with the mineral, allowing control over the size and thereby the magnetic properties of the magnetite crystals by systematically varying the E content. However, systematically varying the $\mathrm{K}$ content allowed $\mathrm{pH}$-dependent control over their dispersibility and thereby their organization, due to the ability of the free $\mathrm{K}$ residues to become protonated.

Particles prepared in the presence of low polypeptide concentrations sediment completely within $24 \mathrm{~h}$, in line with the results with pAsp (Figure S5, Supporting Information). However, for samples synthesized with AA/Fe ratios as high as $1 / 10$ thermogravimetric analysis (TGA) indicated a nearly quantitative polypeptide content of 6-7 wt\% (Figure S12, Supporting Information), and hence a strong binding of the polymer to the resulting crystals. Indeed, they were stable in dispersion for at least 7 days, depending on the $\mathrm{pH}$ and the $\mathrm{K}$ content of the copolypeptide used. Nanoparticles grown in the presence of high $\mathrm{K}$ content ( $>25 \mathrm{~mol} \%$ ) copolypeptides precipitated at $\mathrm{pH} 10$ due to magnetic aggregation, but dispersed well at pH 7 (Figure 5a). This suggests that the increase in electrostatic stabilization upon protonation of the $\mathrm{K}$ residues protects the particles against uncontrolled agglomeration and subsequent precipitation due to the ferrimagnetic attractive forces. Conversely, crystals grown in the presence of lower $\mathrm{K}$ content copolypeptides (which were typically smaller and thus superparamagnetic) lacked sufficient charge stabilization at neutral $\mathrm{pH}$, but formed stable dispersions at high $\mathrm{pH}$ (Figure $5 \mathrm{~b}$ ), presumably due to an increase in the zeta potential of the magnetite. ${ }^{[27]}$ In line with these observations, application of a high E/high $\mathrm{K}$ content copolypeptide, A05, resulted in superparamagnetic crystals with diameter of $12 \pm 5 \mathrm{~nm}$ which were stabilized in dispersion at both neutral and high $\mathrm{pH}$ (Figure S13, Supporting Information).

Cryogenic transmission electron microscopy (cryo-TEM) showed that nanoparticles synthesized in the presence of copolypeptides with higher E content at $\mathrm{pH} 10$ formed disordered aggregates in which many small superparamagnetic particles clustered around the few ferrimagnetic crystals present in the sample (Figure 5d and Figure S14c,d, Supporting Information). In contrast, for the experiments performed using high $\mathrm{K}$ content copolypeptides (>25 mol\%), cryo-TEM showed that at $\mathrm{pH} \mathrm{7,} \mathrm{when} \mathrm{the} \mathrm{ferrimagnetic} \mathrm{nanoparticles} \mathrm{were}$ well-dispersible, they aligned in solution to form long chain-like 

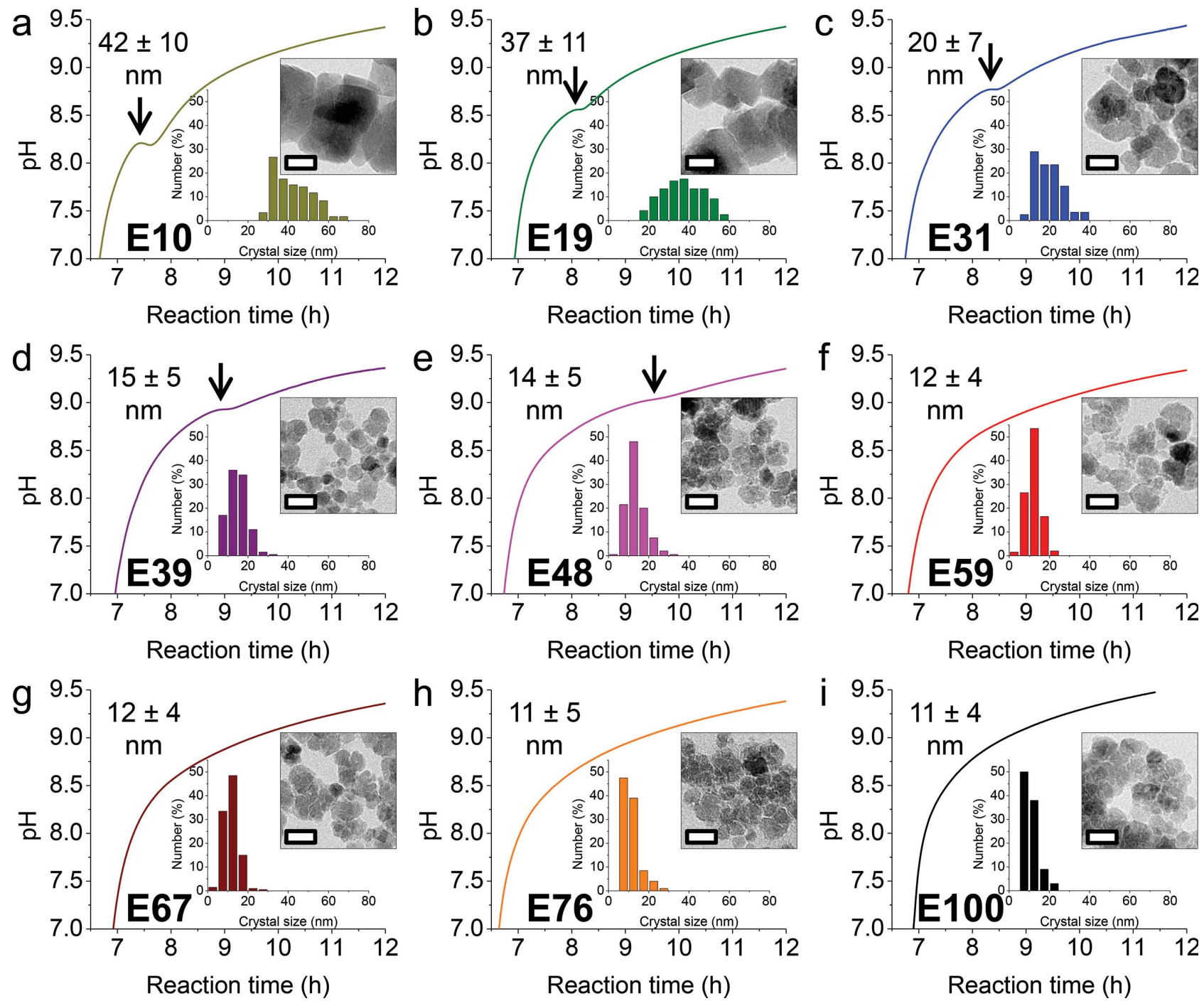

Figure 4. Plots of the magnetite nucleation events during slow coprecipitation by $\mathrm{NH}_{3}$ diffusion in the presence of a-i) different EKA copolypeptides $(\mathrm{AA} / \mathrm{Fe}$ ratio $=1 / 10)$ with resulting crystal size distributions and corresponding TEM images (scale bars are $20 \mathrm{~nm}$ ), showing delayed nucleation at higher $\mathrm{pH}$ resulting in smaller crystals for higher $\mathrm{E}$ contents.

assemblies (Figure 5c and Figure S14a,b, Supporting Information). In line with previous reports, ${ }^{[2,21]}$ this self-assembly was attributed to the alignment of the permanent magnetic dipoles of the ferrimagnetic particles: ${ }^{[24]}$ because the polypeptide additives sterically hinder the aggregation of the particles, particles only assemble along the direction of the magnetic dipole, while bare particles are susceptible to uncontrolled aggregation. In turn, the observed assembly of ferrimagnetic crystals into anisotropic structures may affect their collective magnetic properties in aqueous dispersion. Unfortunately, we cannot address this point unambiguously based on the current VSM data (Figure 3b,c), which were carried out in a gel medium to fixate the magnetite and allow quantification of remnant magnetization and coercivity (see the Supporting Information).

However, consecutive SAED analysis of all crystals in such chains demonstrated that their crystallographic alignment was not perfect, indicating that the magnetic dipoles were not solely aligned along one specific crystallographic direction, which often is the <111> magnetic easy axis in the magnetosome chains of magnetotactic bacteria ${ }^{[29]}$ (see Figure S15 and the discussion in the Supporting Information for more information).

\section{Conclusion}

Our present results show that the slow coprecipitation of magnetite through a ferrihydrite/Fe $\mathrm{F}^{(\mathrm{II})}$ precursor in mildly alkaline aqueous medium using a $\mathrm{NH}_{3}$ diffusion procedure allows manipulation of the nucleation and growth of magnetite crystals through the action of random copolypeptides that, purely based on their amino acid composition, can mimic some functions of the often intrinsically disordered biomineralization proteins. Negatively charged amino acids (aspartic acid, glutamic acid), which stabilize the ferrihydrite $/ \mathrm{Fe}^{(\mathrm{II})}$ precursor through charge interactions and thereby act as magnetite nucleation inhibitors that can control the $\mathrm{pH}$ at which it converts to magnetite, were found to have the most prominent effects. By varying the aspartic acid or 

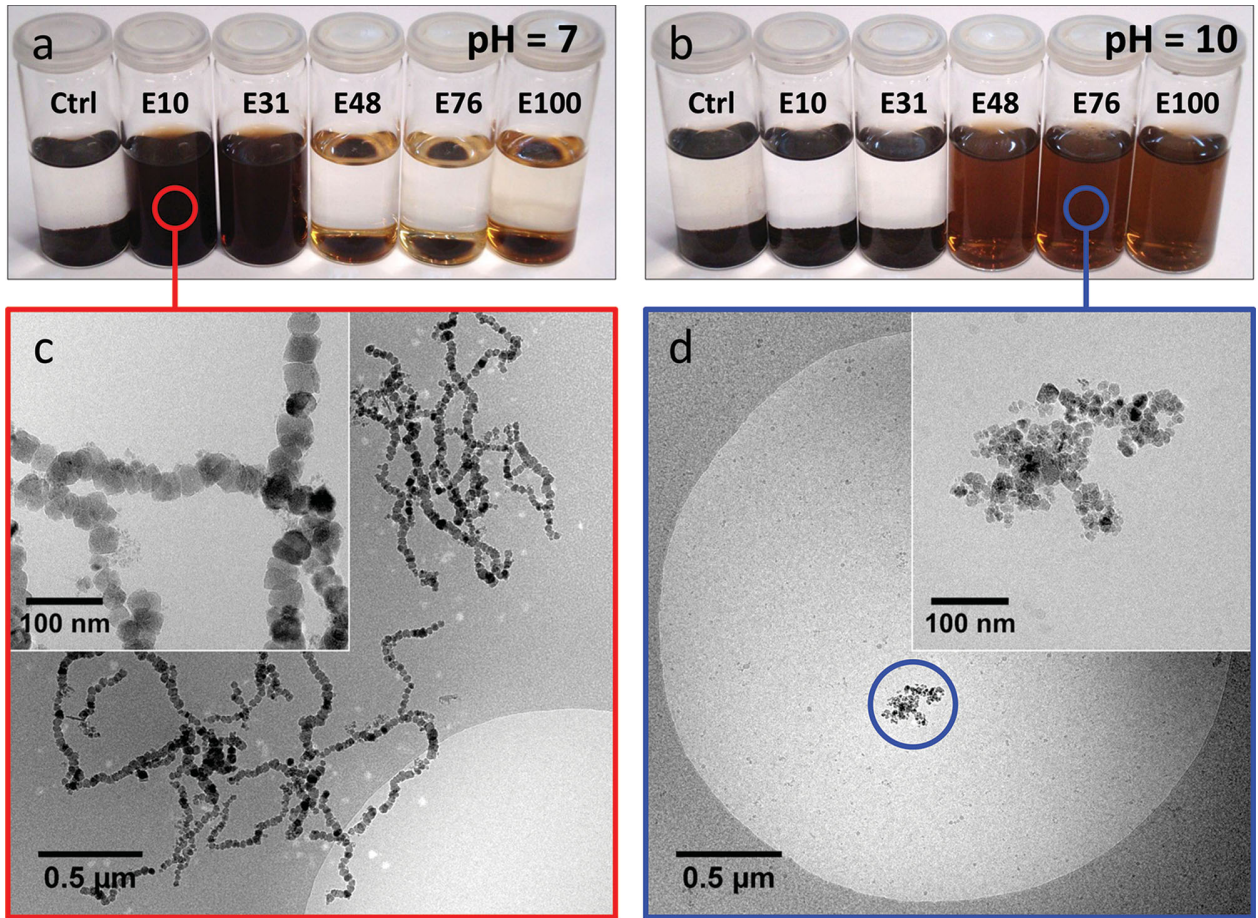

Figure 5. a,b) Pictures of products of slow coprecipitation by $\mathrm{NH}_{3}$ diffusion without additives (Ctrl) and in the presence of different EKA copolypeptides $(\mathrm{AA} / \mathrm{Fe}$ ratio $=1 / 10)$ after 7 days, showing that a) samples with high $\mathrm{K}$ content $(>25$ mol\%) copolypeptides (E10, E31) only disperse well at neutral $\mathrm{pH}$ $(\mathrm{pH} 7)$ and b) samples with low $\mathrm{K}$ content $(<25$ mol\%) copolypeptides (E48, E76, E100) only disperse well at high $\mathrm{pH}(\mathrm{pH} 10)$. The control sample without additives is never dispersible. c,d) Typical cryo-TEM images of products of slow coprecipitation by $\mathrm{NH}_{3}$ diffusion in the presence of $\mathrm{c}$ ) E10 and d) $\mathrm{E76}(\mathrm{AA} / \mathrm{Fe}$ ratio $=1 / 10)$, showing that ferrimagnetic crystals align in solution to form chain-like assemblies and superparamagnetic crystals form disordered aggregates around the few ferrimagnetic crystals present. The insets show higher magnifications.

glutamic acid content of the copolypeptides it therefore was possible to systematically regulate the size and shape and thereby the magnetic properties of the crystals, unlike earlier studies where negatively charged proteins completely inhibited magnetite formation. ${ }^{[21]}$ Further, since the polypeptide additives become immobilized on the surface of the crystals, manipulating the $\mathrm{pH}$ allowed for dispersion/precipitation of the crystals through the protonation/deprotonation of lysine residues, while neutral serine residues did not significantly enhance the dispersibility. Depending on their size and thus their magnetic properties, in such colloidally stable dispersions the crystals self-organized in chain-like assemblies (for $>20 \mathrm{~nm}$, ferrimagnetic crystals) or random aggregates (for $<20 \mathrm{~nm}$, superparamagnetic crystals).

Although our data currently only demonstrate a nonspecific reduction of the crystal dimensions, they still may bear significant implications for future efforts in achieving biomimetic formation and colloidal stabilization of magnetite-based nanomaterials with controlled morphologies and properties using synthetic designer molecules and templates.

\section{Supporting Information}

Supporting Information is available from the Wiley Online Library or from the author.

\section{Acknowledgements}

The work of J.J.M.L. is supported by NanoNextNL, a micro and nanotechnology consortium of the government of The Netherlands and
130 partners. H.R.Z. and A.K. acknowledge the support of the European Research Council via an ERC starting grant (Project No. 240394). N.A.J.M.S. and P.H.H.B. are supported by a $\mathrm{VICl}$ grant of the Dutch Science Foundation - Chemical Sciences (NWO-CW).

Received: October 14, 2014

Revised: November 13, 2014 Published online: December 17, 2014

[1] V. Dmitrović, J. J. M. Lenders, H. R. Zope, G. de With, A. Kros, N. A. J. M. Sommerdijk, Biomacromolecules 2014, 15, 3687.

[2] J. J. M. Lenders, C. L. Altan, P. H. H. Bomans, A. Arakaki, S. Bucak, G. de With, N. A. J. M. Sommerdijk, Cryst. Growth Design 2014, 14, 5561.

[3] a) T. Prozorov, D. A. Bazylinski, S. K. Mallapragada, R. Prozorov, Mater. Sci. Eng.: R: Rep. 2013, 74, 133; b) R. F. Butler, S. K. Banerjee, J. Geophys. Res. 1975, 80, 4049; c) Ö. Özdemir, D. J. Dunlop, B. M. Moskowitz, Earth Planetary Sci. Lett. 2002, 194, 343; d) G. F. Goya, T. S. Berquo, F. C. Fonseca, M. P. Morales, J. Appl. Phys. 2003, 94, 3520; e) J. Santoyo Salazar, L. Perez, O. de Abril, L. Truong Phuoc, D. Ihiawakrim, M. Vazquez, J.-M. Greneche, S. Begin-Colin, G. Pourroy, Chem. Mater. 2011, 23, 1379.

[4] a) D. Faivre, D. Schüler, Chem. Rev. 2008, 108, 4875; b) R. Blakemore, Science 1975, 190, 377; c) B. Devouard, M. Posfai, X. Hua, D. A. Bazylinski, R. B. Frankel, P. R. Buseck, Am. Mineralogist 1998, 83, 1387.

[5] a) J. L. Kirschvink, M. M. Walker, C. E. Diebel, Curr. Opinion Neurobiol. 2001, 11, 462; b) R. C. Beason, J. E. Nichols, Nature 1984, 309, 151. 
[6] C.-Y. Hsu, C.-W. Li, Science 1994, 265, 95.

[7] C. E. Diebel, R. Proksch, C. R. Green, P. Neilson, M. M. Walker, Nature 2000, 406, 299

[8] a) M. Kiyama, Bull. Instit. Chem. Res., Kyoto Univ. 1970, 47, 607; b) R. Massart, Mag., IEEE Trans. 1981, 17, 1247; c) T. Ahn, J. H. Kim, H.-M. Yang, J. W. Lee, J.-D. Kim, J. Phys. Chem. C 2012, 116, 6069; d) A.-H. Lu, E. L. Salabas, F. Schüth, Angew. Chem. Int. Ed. 2007, 46, 1222; e) S. Laurent, D. Forge, M. Port, A. Roch, C. Robic, L. Vander Elst, R. N. Muller, Chem. Rev. 2008, 108, 2064.

[9] F. Nudelman, N. A. J. M. Sommerdijk, Angew. Chem. Int. Ed. 2012, $51,6582$.

[10] a) N. A. J. M. Sommerdijk, G. de With, Chem. Rev. 2008, 108, 4499; b) M. J. Olszta, X. Cheng, S. S. Jee, R. Kumar, Y.-Y. Kim, M. J. Kaufman, E. P. Douglas, L. B. Gower, Mater. Sci. Eng.: R: Rep. 2007, 58, 77; c) E. G. Vrieling, Q. Sun, T. P. M. Beelen, S. Hazelaar, W. W. C. Gieskes, R. A. Van Santen, N. A. J. M. Sommerdijk, J. Nanosci. Nanotechnol. 2005, 5, 68 .

[11] a) R. B. Frankel, G. C. Papaefthymiou, R. P. Blakemore, W. O'Brien, Biochim. Biophys. Acta 1983, 763, 147; b) S. Mann, R. B. Frankel, R. P. Blakemore, Nature 1984, 310, 405; c) S. Watanabe, M. Yamanaka, A. Sakai, K. Sawada, T. Iwasa, Mater. Trans. 2008, 49, 874; d) J. Baumgartner, G. Morin, N. Menguy, T. Perez Gonzalez, M. Widdrat, J. Cosmidis, D. Faivre, Proc. Natl. Acad. Sci. U.S.A 2013, 110, 14883; e) M. L. Fdez-Gubieda, A. Muela, J. Alonso A. García-Prieto, L. Olivi, R. Fernández-Pacheco, J. M. Barandiarán, ACS Nano 2013, 7, 3297; f) M. I. Siponen, P. Legrand, M. Widdrat, S. R. Jones, W.-J. Zhang, M. C. Y. Chang, D. Faivre, P. Arnoux, D. Pignol, Nature 2013, 502, 681.

[12] a) H. A. Lowenstam, Science 1967, 156, 1373; b) K. M. Towe, H. A. Lowenstam, J. Ultrastruct. Res. 1967, 17, 1; c) J. Kirschvink, H. Lowenstam, Earth Planetary Sci. Lett. 1979, 44, 193; d) K.-S. Kim, D. J. Macey, J. Webb, S. Mann, Proc. R. Soc. London. Ser. B: Biol. Sci. 1989, 237, 335; e) Q. Wang, M. Nemoto, D. Li, J. C. Weaver, B. Weden, J. Stegemeier, K. N. Bozhilov, L. R. Wood, G. W. Milliron, C. S. Kim, E. DiMasi, D. Kisailus, Adv. Funct. Mater. 2013, 23, 2908; f) L. M. Gordon, J. K. Román, R. M. Everly, M. J. Cohen, J. J. Wilker, D. Joester, Angew. Chem. Intl. Ed. 2014, 53, 11506.

[13] In the magnetosomes, first a poorly ordered phosphate-rich ferric hydroxide phase is precipitated which only later on transforms at high $\mathrm{pH}$ via ferrihydrite to the final magnetite, either through a partial reduction step or the subsequent addition of $\mathrm{Fe}^{(\mathrm{II})}$, facilitated by both $\mathrm{Fe}^{\left({ }^{(I I)}\right)}$ reductases and $\mathrm{Fe}^{\left({ }^{(I)}\right)}$ cation diffusion facilitators: a) R. Uebe, K. Junge, V. Henn, G. Poxleitner, E. Katzmann, J. M. Plitzko, R. Zarivach, T. Kasama, G. Wanner, M. Pósfai, L. Böttger, B. Matzanke, D. Schüler, Mol. Microbiol. 2011, 82, 818; b) C. Zhang, X. Meng, N. Li, W. Wang, Y. Sun, W. Jiang, G. Guan, Y. Li, J. Bacteriol. 2013, 195, 876.

[14] Y. A. Gorby, T. J. Beveridge, R. P. Blakemore, J. Bacteriol. 1988, 170 834.
[15] a) K. Grünberg, C. Wawer, B. M. Tebo, D. Schüler, Appl. Environ. Microbiol. 2001, 67, 4573; b) S. Schübbe, M. Kube, A. Scheffel, C. Wawer, U. Heyen, A. Meyerdierks, M. H. Madkour, F. Mayer, R. Reinhardt, D. Schüler, J. Bacteriol. 2003, 185, 5779; c) A. Arakaki, J. Webb, T. Matsunaga, J. Biol. Chem. 2003, 278, 8745; d) A. Scheffel, A. Gärdes, K. Grünberg, G. Wanner, D. Schüler, J. Bacteriol. 2008, 190, 377.

[16] a) T. Prozorov, S. K. Mallapragada, B. Narasimhan, L. Wang P. Palo, M. Nilsen-Hamilton, T. J. Williams, D. A. Bazylinski, R. Prozorov, P. C. Canfield, Adv. Funct. Mater. 2007, 17, 951; b) Y. Amemiya, A. Arakaki, S. S. Staniland, T. Tanaka, T. Matsunaga, Biomaterials 2007, 28, 5381; c) A. Arakaki, F. Masuda, Y. Amemiya, T. Tanaka, T. Matsunaga, J. Colloid Interface Sci. 2010, 343, 65; d) J. M. Galloway, J. P. Bramble, A. E. Rawlings, G. Burnell, S. D. Evans, S. S. Staniland, Small 2012, 8, 204.

[17] a) J. S. Evans, Chem. Rev. 2008, 108, 4455; b) G. K. Hunter, J. O'Young, B. Grohe, M. Karttunen, H. A. Goldberg, Langmuir 2010, 26, 18639; c) L. Kalmar, D. Homola, G. Varga, P. Tompa, Bone 2012, 51, 528

[18] L. Wang, T. Prozorov, P. E. Palo, X. Liu, D. Vaknin, R. Prozorov, S. Mallapragada, M. Nilsen-Hamilton, Biomacromolecules 2011, 13, 98.

[19] a) W. Wu, Q. He, C. Jiang, Nanoscale Res. Lett. 2008, 3, 397; b) T. Indira, P. Lakshmi, Int. J. Pharm. Sci. Nanotechnol. 2010, 3, 1035.

[20] a) J. Baumgartner, A. Dey, P. H. H. Bomans, C. Le Coadou, P. Fratzl, N. A. J. M. Sommerdijk, D. Faivre, Nat. Mater. 2013, 12, 310; b) J. Baumgartner, L. Bertinetti, M. Widdrat, A. M. Hirt, D. Faivre, PLOS ONE 2013, 8, e57070.

[21] J. Baumgartner, M. Antonietta Carillo, K. M. Eckes, P. Werner, D. Faivre, Langmuir 2014, 30, 2129.

[22] A. S. Schenk, H. Zope, Y.-Y. Kim, A. Kros, N. A. Sommerdijk, F. C. Meldrum, Faraday Discuss. 2012, 159, 327.

[23] These copolypeptides previously have been used successfully in the biomimetic synthesis of calcium carbonate $\left(\mathrm{CaCO}_{3}\right)^{[22]}$

[24] M. Klokkenburg, C. Vonk, E. M. Claesson, J. D. Meeldijk, B. H. Erné, A. P. Philipse, J. Am. Chem. Soc. 2004, 126, 16706.

[25] S. Ziemniak, M. Jones, K. Combs, J. Solution Chem. 1995, 24, 837.

[26] L. Vayssières, C. Chanéac, E. Tronc, J. P. Jolivet, J. Colloid Interface Sci. 1998, 205, 205-212.

[27] S. Vidojkovic, V. Rodriguez-Santiago, M. V. Fedkin, D. J. Wesolowski, S. N. Lvov, Chem. Eng. Sci. 2011, 66, 4029.

[28] C. L. Altan, J. J. M. Lenders, P. H. H. Bomans, G. de With, H. Friedrich, S. Bucak, N. A. J. M. Sommerdijk, Chem. Eur. J. 2014, under review.

[29] a) F. C. Meldrum, S. Mann, B. R. Heywood, R. B. Frankel, D. A. Bazylinski, Proc. R. Soc. London. Ser. B: Biol. Sci. 1993, 251, 231; b) R. E. Dunin-Borkowski, M. R. McCartney, R. B. Frankel, D. A. Bazylinski, M. Pósfai, P. R. Buseck, Science 1998, 282, 1868; c) A. Körnig, M. Winklhofer, J. Baumgartner, T. P. Gonzalez, P. Fratzl, D. Faivre, Adv. Funct. Mater. 2014, 24, 3926. 